\title{
THE BASAL SLIDING OF A THINNING ICE SHEET, MIZUHO PLATEAU, EAST ANTARGTICA
}

\author{
By Shinji MaE \\ (National Institute of Polar Research, Kaga, Itabashi-ku, Tokyo, Japan)
}

\begin{abstract}
The Japanese Antarctic Research Expedition observed the thinning of the ice sheet, about $70 \mathrm{~cm} /$ year, in Mizuho Plateau. The thinning observed is analysed using an equation of mass continuity. The result of the analysis indicates that the thinning is predominantly caused by the basal sliding and the basal sliding velocity is about $10 \mathrm{~m} /$ year. This sliding velocity is compared with the basal sliding velocity obtained by the calculation of the velocity due to internal deformation of ice sheet.

RÉsumÉ. Le glissement à la base d'une calotte glaciaire en voie d'amincissement, Mizuho Plateau, Est Antarctique. L'expédition antarctique japonaise a observé l'amincissement de la couverture de glace, qui est d'environ $70 \mathrm{~cm}$ par an, sur le Mizuho Plateau. Cet amincissement observé est analysé en utilisant une équation de continuité de masse. Les résultats de l'analyse indiquent que l'amincissement a pour cause prédominante le glissement au sol et que la vitesse du glissement au sol est d'environ $10 \mathrm{~m} / \mathrm{an}$. Cette vitesse de glissement est comparée avec celle obtenue par le calcul à partir de la déformation interne de la couverture de glace.

Zusammenfassung. Das Gleiten am Untergrund eines dünner werdenden Eisschildes, Mizuho-Plateau, Ostantarktis. Die Japanese Antarctic Research Expedition stellte eine Ausdünnung des Eisschildes auf dem MizuhoPlateau um ca $70 \mathrm{~cm}$ pro Jahr fest. Die beobachtete Ausdünnung wird mit Hilfe einer Massenkontinuitätsgleichung analysiert. Es zeigt sich, dass die Ausdünnung im wesentlichen durch das Gleiten am Untergrund verursacht wird, dessen Geschwindigkeit etwa $10 \mathrm{~cm}$ pro Jahr beträgt. Diese Gleitgeschwindigkeit wird mit der aus der inneren Deformation des Eisschildes berechneten verglichen.
\end{abstract}

\section{Introduction}

The Japanese Antarctic Research Expedition (JARE) carried out its glaciological research programme in Mizuho Plateau during the period from I968 to 1975. The main objects of the programme were the measurements of mass balance, ice flow, and surface and sub-glacial topography in Mizuho Plateau (Shimizu, 1978). The measurements of ice flow were made using the triangulation net set up along the traverse route shown in Figure $I$ (Naruse, 1978, 1979). The possible error of the survey resulting from refraction in the atmosphere and curvature of the Earth was counterbalanced because the vertical angles were measured twice from two positions of the triangulation net in opposite directions, and the angles were averaged. The triangulation net, of which the starting point was fixed on rock in the Yamato Mountains, was surveyed by the Ioth JARE during the period between November and December i969. It was resurveyed by the I 4 th JARE during the period between December 1973 and January 1974 .

Naruse (1978, I979) analysed the survey result of the triangulation net and estimated the horizontal and vertical velocities of the ice surface and strain-rate at the surface. Taking into account the effect of the firn densification, he estimated the rate of change $h$ of the ice thickness $h$. The mean-square error of the vertical movement is $18 \mathrm{~cm} /$ year at point $\mathrm{A}$ and $3 \mathrm{I} \mathrm{cm} /$ year at point c. The mean-square error of $h$ is approximately equal to that of the vertical movement. The results of this estimation revealed that the main part of the route in the Mizuho Plateau was thinning by $70 \mathrm{~cm} /$ year. Along the route, the accumulation-rate of snow was measured during this period (Yokoyama, 1975) and the ice thickness and bedrock topography were observed using radio echo-sounding (Naruse and Yokoyama, I975; Shimizu and others, 1978). Reinterpreting the radio echo observed, Mae (1978) obtained improved bedrock topography.

Mae (1977) and Mae and Naruse (1978) investigated a possible cause of the thinning of the ice sheet in Mizuho Plateau and reported their preliminary conclusion that the thinning was not caused by a decrease of the accumulation-rate due to a change in climate but by basal sliding of which the velocity was about ro m/year. In this paper the preliminary work is developed and the stability of the ice sheet in Mizuho Plateau is discussed. 


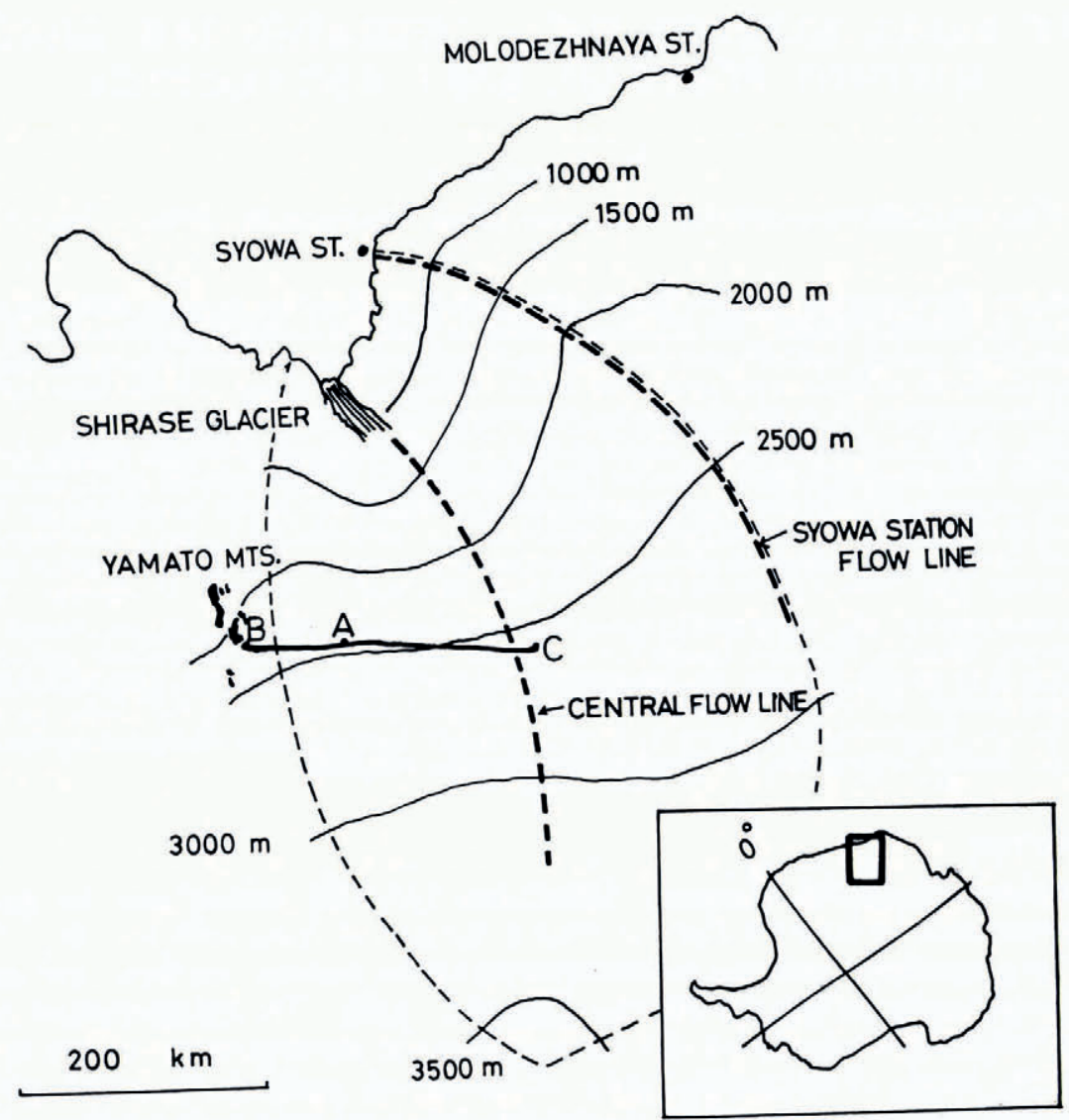

Fig. 1. Map of the Mizuho Plateau. A thick line represents the traverse route. Thin solid lines represent equal-elevation contours. Thin dashed lines represent the boundary of the Shirase Glacier drainage basin.

2. BASAl SLIDING VElocity ESTIMATED USING THE EQUATION OF MASS GONTINUITY

The values of $h$ calculated by Naruse (1978) are shown in Figure 2. The error in the vertical movement caused by refraction in the atmosphere and curvature of the Earth was eliminated and the mean-square error of the vertical movement is $18 \mathrm{~cm} /$ year at point $\mathrm{A}$ (Fig. I) and $3^{1} \mathrm{~cm} /$ year at point c (Fig. I) (Naruse, 1978). The error in $h$ is approximately equal to that of the vertical movement. Thus it is seen from Figure 2 that $h$ is about zero between points $\mathrm{A}$ and $\mathrm{B}$ and about $-70 \mathrm{~cm} /$ year between points $\mathrm{A}$ and $\mathrm{c}$.

Yokoyama (1975) measured the accumulation-rate of snow along the route. The accumulation-rate $\dot{a}$ of ice calculated from Yokoyama's measurement is about $7 \mathrm{~cm} /$ year on average along the route and even the maximum value of $\dot{a}$ is about $30 \mathrm{~cm} /$ year. In the coastal area near Syowa Station (Fig. I) where cyclones can occur and the amount of snow precipitation is large, $\dot{a}$ rarely exceeds about $50 \mathrm{~cm} /$ year (Yamada and others, 1978). This suggests that $h$ is too large to be compensated by the present value of snow accumulation-rate observed in the Mizuho Plateau and temporal variation of the accumulation-rate cannot account for the large value of $-h$.

For the study of the thickness change of the ice sheet, a very useful equation is that of mass continuity. The equation of mass continuity for an ice sheet is given by Shumskiy and Bauer 


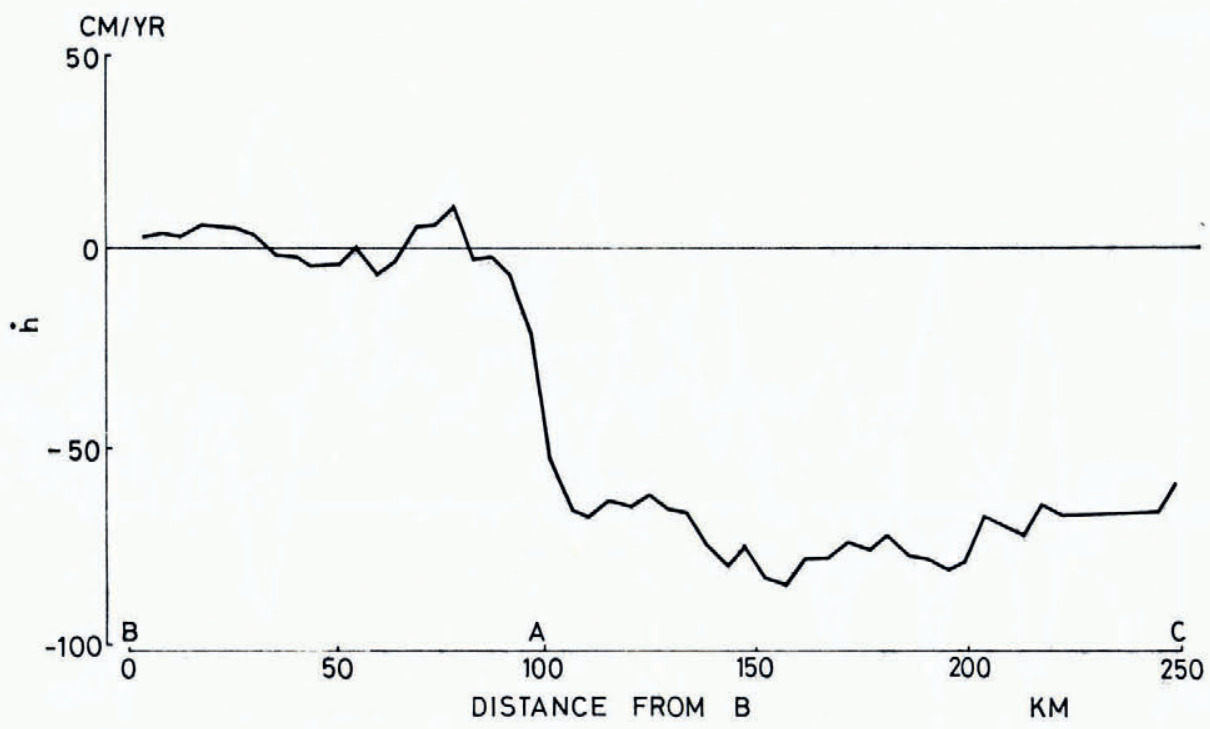

Fig. 2. The rate of change $h$ of the ice thickness along the traverse route.

(1965). Taking the $x$-axis along the horizontal component of flow velocity, they obtain the equation

$$
\frac{\partial m}{\partial t}=\rho_{\mathrm{s}} \dot{a}+\rho_{\mathrm{b}} \dot{b}-\int_{z_{\mathrm{b}}}^{z_{\mathrm{s}}} \rho\left(\dot{\epsilon}_{x}+\dot{\epsilon}_{y}\right) \mathrm{d} z-\int_{z_{\mathrm{b}}}^{z_{\mathrm{s}}} u \frac{\partial \rho}{\partial x} \mathrm{~d} z+\rho_{\mathrm{s}} u_{\mathrm{s}} \tan \alpha_{\mathrm{s}}-\rho_{\mathrm{b}} u_{\mathrm{b}} \tan \alpha_{\mathrm{b}},
$$

where $m$ is the mass of a vertical column with unit area of horizontal cross-section at a given point $(x, y), \rho(z)$ is the density of ice and firn, $\dot{\epsilon}$ is strain-rate, $b$ is the accumulation-rate at bottom, $u$ is the velocity in the $x$ direction, and $\alpha$ is the slope. Roman subscripts s (for surface) and $b$ (for bottom) denote the position where the value is to be taken. The ice thickness is given by $h=z_{\mathrm{s}}-z_{\mathrm{b}}$.

In the present case, since the firn densification is eliminated in the calculation of $h, \rho$ is approximately constant and equal to the density of ice and $\partial \rho / \partial x=0 . \alpha_{\mathrm{S}}$ and $\alpha_{\mathrm{b}}<\mathrm{I}$, so $\tan \alpha_{\mathrm{s}} \simeq \alpha_{\mathrm{s}}$ and $\tan \alpha_{\mathrm{b}} \simeq \alpha_{\mathrm{b}}$. If we assume that the vertical strain-rate is independent of depth and the freezing or melting rate is neglected, Equation (I) can be rewritten

$$
h=\dot{a}-\left(\dot{\epsilon}_{x}+\dot{\epsilon}_{y}\right) h+u_{\mathbf{s}} \alpha_{\mathbf{s}}-u_{\mathbf{b}} \alpha_{\mathbf{b}} .
$$

Substituting the observed values of $h, \dot{a}, \dot{\boldsymbol{\epsilon}}_{x}+\dot{\boldsymbol{\epsilon}}_{y}, h, u_{\mathrm{s}}$, and $\alpha_{\mathrm{s}}$ into Equation (2), we obtain $u_{\mathrm{b}} \alpha_{\mathrm{b}}$ which is shown in Figure 3 .

The flow lines on the traverse route generally converge slightly (Naruse, 1978). However, when the convergence or divergence of the flow lines is large, the strain-rate, $\dot{\boldsymbol{\epsilon}}_{x}+\dot{\epsilon}_{y}$, is extraordinarily large or small, as shown in Figure 3; we should not use Equation (2) at such points. Excluding the large strain-rates, Figure 3 indicates that $u_{\mathrm{b}} \alpha_{\mathrm{b}} \approx 0$ between points A and B and $u_{\mathrm{b} \alpha_{\mathrm{b}}} \simeq 55 \mathrm{~cm} /$ year in average between points $\mathrm{A}$ and $\mathrm{c}$. This large value of $u_{\mathrm{b}} \alpha_{\mathrm{b}}$ between points $\mathrm{A}$ and c suggests that $u_{\mathrm{b}}$ is significantly large and the thinning of the ice sheet may be predominantly caused by the basal sliding because $u_{\mathrm{b}} \alpha_{\mathrm{b}} \gg \dot{a}+u_{\mathrm{s}} \alpha_{\mathrm{s}}-\left(\dot{\epsilon}_{x}+\dot{\epsilon}_{y}\right) h$. The result of the radio echo-sounding shows that the slope of the bedrock is large below the route while it is small down-glacier (Shimizu and others, I978; Mae, 1978). Mae (1977) estimated $\alpha_{\mathbf{b}}$ at point $\mathrm{c}$ to be about $4 \times 10^{-2}$. Since $u_{\mathrm{b}} \alpha_{\mathrm{b}}=45 \mathrm{~cm} /$ year at point $\mathrm{c}, u_{\mathrm{b}}$ is about $10 \mathrm{~m} /$ year. 


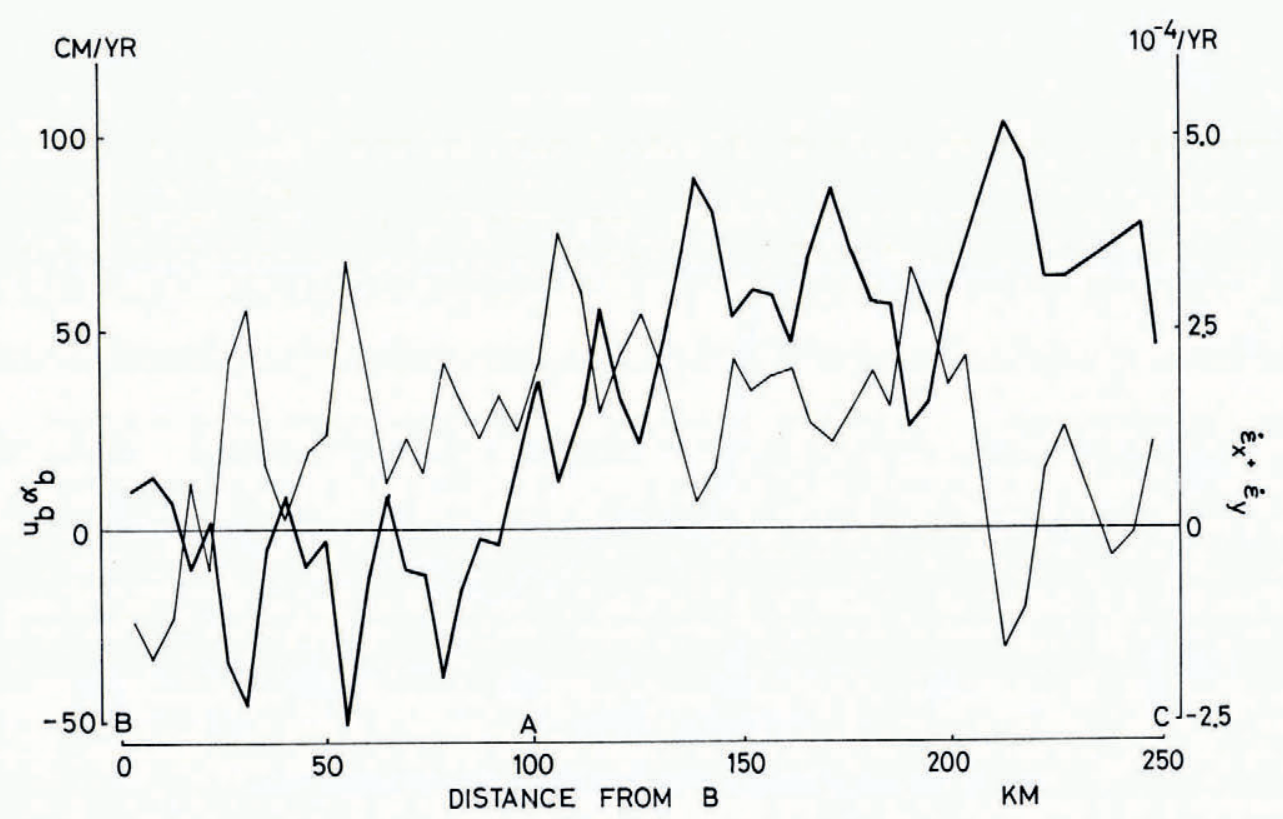

Fig. 3. $u_{\mathrm{b}} \alpha_{\mathrm{b}}$ (thick line) and $\dot{\boldsymbol{\epsilon}}_{x}+\dot{\epsilon}_{y}$ (thin line) along the traverse route.

It is impossible to estimate $\alpha_{\mathrm{b}}$ below the traverse route but it appears that $\alpha_{\mathrm{b}}$ is approximately equal to $\alpha_{\mathrm{b}}$ at point $\mathrm{c}$. Therefore, between points $\mathrm{A}$ and $\mathrm{c}$ the velocity of basal sliding may be Io $\mathrm{m} /$ year and between points $\mathrm{A}$ and $\mathrm{B}$ it may be zero.

We assume that $\dot{\epsilon}_{x}+\dot{\epsilon}_{y}$ and $\rho$ are independent of depth. Dansgaard and Johnsen (Ig6g) calculated the temperature profile in the ice sheet and compared it with that observed at Camp Century, Greenland. From the comparison they showed that the profile was considerably improved if they used a vertical strain-rate that was uniform down to some $400 \mathrm{~m}$ or so above the bottom of the ice, and then decreased to zero at bedrock, instead of using a uniform strain-rate (the ice thickness at Camp Century is about I $400 \mathrm{~m}$ ). If the model with a nonuniform strain-rate is right, the term $\int_{z \mathrm{~b}}^{z_{\mathrm{s}}} \rho\left(\dot{\epsilon}_{x}+\dot{\epsilon}_{y}\right) \mathrm{d} z$ of Equation (I) decreases by about $20 \%$ while $u_{\mathrm{b}} \alpha_{\mathrm{b}}$ increases by about $6 \mathrm{~cm} /$ year between points A and в. If we take $0.7 \mathrm{Mg} / \mathrm{m}^{3}$ for $\rho_{\mathrm{s}}$, the summation $\rho_{\mathrm{s}} \dot{a}+\rho_{\mathrm{s}} u_{\mathrm{s}} \tan \alpha_{\mathrm{s}}$ of Equation (I) decreases by about $5 \mathrm{~cm} /$ year but the other terms of Equation (I) hardly change, so that $u_{\mathrm{b}} \alpha_{\mathbf{b}}$ decreases by about $5 \mathrm{~cm} /$ year between points $\mathrm{A}$ and $\mathrm{C}$ about $3 \mathrm{~cm} /$ year between points $\mathrm{A}$ and $\mathrm{B}$. Thus, the variation of $u_{\mathrm{b}} \alpha_{\mathrm{b}}$ due to the assumptions is within the mean-square error of $h$ and can be ignored in the estimation of $u_{\mathrm{b}}$.

\section{BASAl SLIDing Velocity estimated USing the FLOW LAW OF ICE}

The surface velocity $u_{\mathrm{s}}$ is given by

$$
u_{\mathrm{s}}=u_{\mathrm{p}}+u_{\mathrm{b}},
$$

where $u_{\mathrm{p}}$ is the velocity due to the plastic deformation of the ice mass. The calculation of $u_{\mathrm{s}}$ is complicated because of the dependence of strain-rate upon temperature. The temperature 
profile in the Mizuho Plateau has not yet been observed. However, Nishio and Mae (in press) calculated the temperature profile using a steady-state model used by Robin (1955) under an assumption that the ice sheet was in equilibrium, because Mae (1977) and Mae and Naruse (1978) considered that the thinning commenced within $\mathrm{IO}^{3}$ years B.P. and F. Nishio (private communication) proposed, on the basis of the analysis of the temperature observations of a core hole at Mizuho Station, that the thinning commenced about a few hundred years ago. The profile calculated shows that the base temperature is at the melting point between points $\mathrm{A}$ and $\mathrm{G}$ and the base is frozen near the Yamato Mountains. This may be evidence that basal sliding occurs between points A and c.

H. Shōji (private communication; an abstract is presented in this symposium, Shōji and Higashi (1979)) carried out deformation tests under high hydrostatic pressures with core-ice specimens obtained from various depths at Byrd Station in order to examine the deformation behaviour of ice masses inside the ice sheet. The results of the test revealed that above a depth of about I $200 \mathrm{~m}$ the ice was soft because of air bubbles, while below this depth the ice became hard because of the closure of air bubbles, and the relation between the shear strain-rate on the slip plane $\dot{\gamma}_{x z}$ and the shear stress $\tau_{x z}$ is as follows:

depth $d \leqslant \mathrm{I} 200 \mathrm{~m}$

$$
\dot{\gamma}_{x z}=\left(6.5 \times \mathrm{IO}^{5} \mathrm{bar}^{-3} \mathrm{~s}^{-1}\right) \tau_{x z^{3}} \exp \left(-\frac{Q}{R T}\right),
$$

where $Q=66 \mathrm{~kJ} / \mathrm{mol}$ and $R$ is the gas constant;

I $200 \mathrm{~m} \leqslant d \leqslant D$ (the depth where the temperature is $-8^{\circ} \mathrm{C}$ )

where $Q=66 \mathrm{~kJ} / \mathrm{mol}$;

$$
\dot{\gamma}_{x z}=\left(\mathrm{I} .2 \times \mathrm{IO}^{3} \mathrm{bar}^{-3} \mathrm{~s}^{-1}\right) \tau_{x z^{3}} \exp \left(-\frac{Q}{R T}\right),
$$

$D \leqslant d$

$$
\dot{\gamma}_{x z}=\left(7.8 \times \mathrm{IO}^{14} \mathrm{bar}^{-3} \mathrm{~s}^{-1}\right) \tau_{x z^{3}} \exp \left(-\frac{Q}{R T}\right),
$$

where $Q=126 \mathrm{~kJ} / \mathrm{mol}$.

Using Shōji's result and the temperature profile obtained by Nishio and Mae (in press) and assuming that the ice-sheet flow is laminar, $u_{\mathrm{p}}$ is calculated as shown in Figure 4 . The sliding velocity $u_{\mathrm{b}}$ is given by $u_{\mathrm{s}}-u_{\mathrm{p}}$; it is about $\mathrm{I}_{\mathrm{I}}$ to $15 \mathrm{~m} / \mathrm{year}$, which is approximately equal to the value for $u_{\mathrm{b}}$ obtained in the previous section. If we assume that the stress-strainrate relation is expressed by

$$
\dot{\gamma}_{x z}=B \tau_{x z^{3}} \exp \left(-\frac{Q}{R T}\right),
$$

throughout the whole depth and $u_{\mathrm{b}}$ is about $10 \mathrm{~m} /$ year, we obtain $B=3 \times 10^{3} \mathrm{bar}^{-3} \mathrm{~s}^{-1}$ and $Q=66 \mathrm{~kJ} / \mathrm{mol}$. These values are approximately equal to those used by Hughes (1973) for his calculation of the internal deformation velocity of the West Antarctic ice sheet.

Paterson (1977) obtained the stress-strain-rate relation using the measured bore-hole closure rates. The data of the rates cover temperatures between $-16^{\circ} \mathrm{C}$ and $-28^{\circ} \mathrm{C}$ and depths down to about $300 \mathrm{~m}$. The obtained relation is given by

$$
\dot{\gamma}_{x z}=\left(2.04 \mathrm{bar}^{-3} \mathrm{~s}^{-1}\right) \tau_{x z^{3}} \exp \left(-\frac{Q}{R T}\right),
$$

where $Q=54 \mathrm{~kJ} / \mathrm{mol}$. For a given stress the strain-rates measured by Shōji are 2 to 8 times larger than Paterson's result. If we use Paterson's result, the calculated $u_{\mathrm{p}}$ is 3 to 4 times smaller than the $u_{\mathrm{p}}$ shown in Figure 4 . 


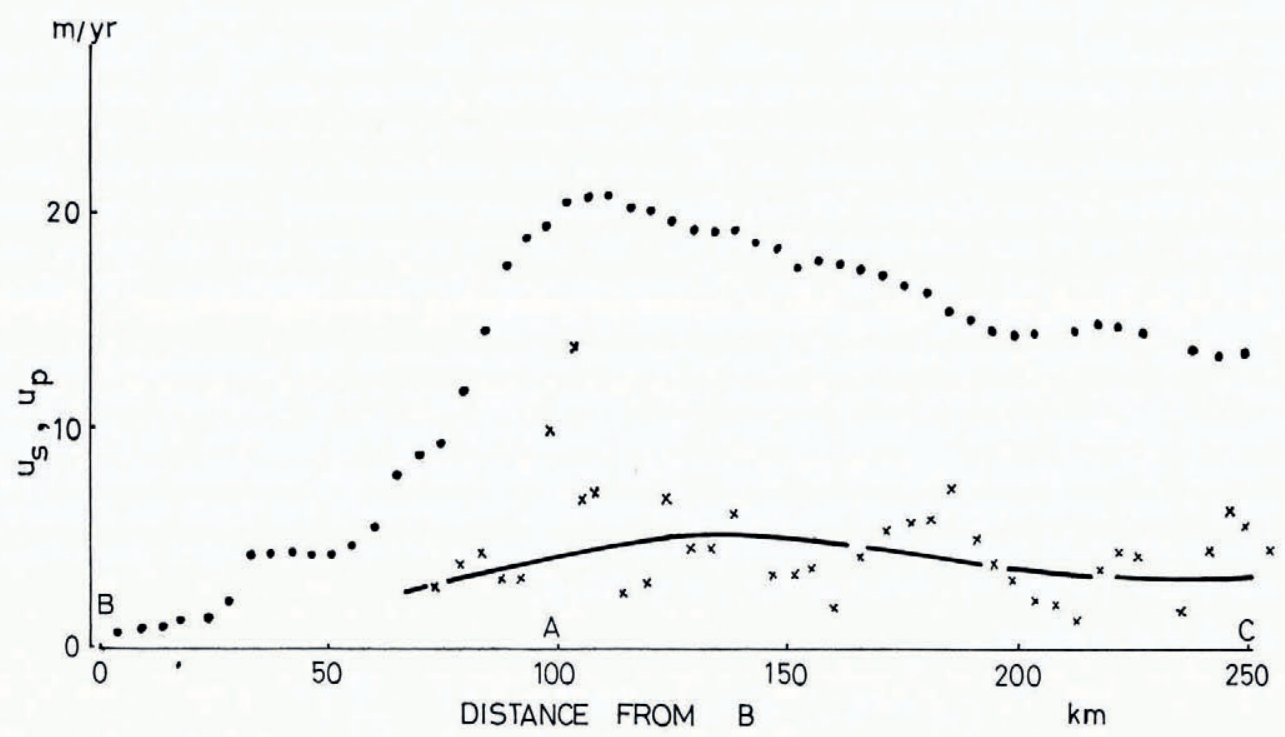

Fig. 4. The horizontal surface velocity, $u_{\mathrm{s}}$ (from Naruse, 1978 ), and the velocity $u_{\mathrm{p}}$ due to plastic deformation along the traverse route are represented by and $\times$. The thick line represents the smoothed curve of $u_{\mathrm{p}}$.

\section{BAsAl SHEAR STRESS}

The thinning caused by basal sliding suggests that the ice sheet of the Mizuho Plateau may be in an unstable state at present. The basal shear stress $\tau_{\mathfrak{b}}$ is an important parameter to examine the state of ice sheet. It is given by

$$
\tau_{\mathrm{b}}=\rho g h \sin \alpha_{\mathrm{s}} .
$$

Substituting the observed values of $h$ and $\alpha_{\mathrm{S}}$ along the traverse route into Equation (4), we obtain $\tau_{\mathrm{b}}$ as shown in Figure 5 . It is seen from Figure 5 that $\tau_{\mathrm{b}}$ is approximately $\mathrm{I}$ bar. The deviation of $\tau_{\mathrm{b}}$ from I bar is mainly caused by the fluctuation of $\alpha_{\mathrm{s}}$ due to the micromorphology of the ice surface.

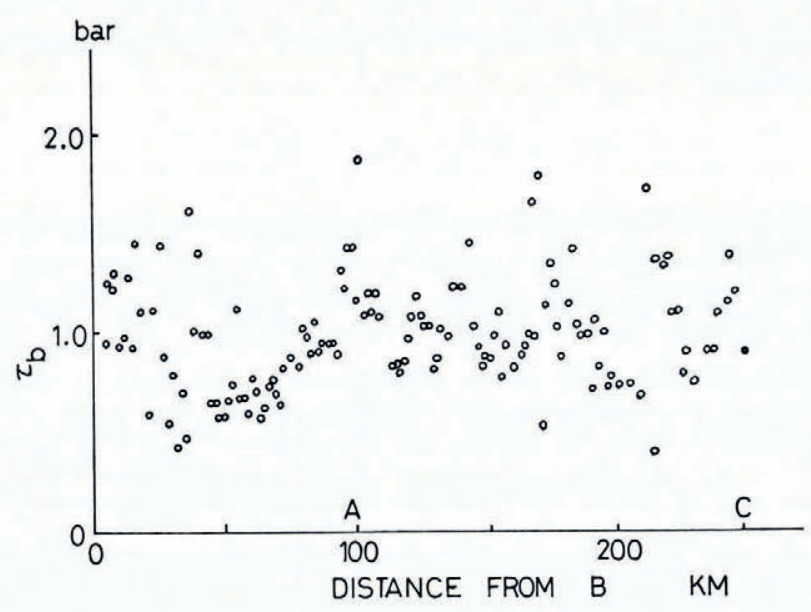

Fig. 5. The basal shear stress $\tau_{\mathrm{b}}$ along the traverse route. 
The main part of the traverse route flows into the Shirase Glacier, as shown in Figure I. Then, $\tau_{\mathrm{b}}$ along the central flow line of the Shirase Glacier drainage basin and $\tau_{\mathrm{b}}$ along the ridge of the basin, the Syowa Station flow line, are calculated based on the surface and bedrock morphology shown in Figure 6 and JARE observations. $\tau_{\mathrm{b}}$ along the central flow line increases with increasing distance from the coast, reaches a maximum value of $\mathrm{r} .8 \mathrm{bar}$ around $\mathrm{r}$ oo $\mathrm{km}$ from the coast, and then gradually decreases. On the other hand, $\tau_{\mathbf{b}}$ along the Syowa Station flow line decreases drastically near the coast and shows a slight decrease in the inland area. The increase in $\tau_{\mathrm{b}}$ along the central flow line for $100 \mathrm{~km}$ from the coast arises from the increase in $h$, while the decrease in $\tau_{\mathrm{b}}$ beyond $\mathrm{r}$ oo $\mathrm{km}$ from the coast is caused by the decrease in $\alpha_{\mathrm{s}}$. The curve of $\tau_{\mathrm{b}}$ along the central flow line is very similar to those of glaciers in a pre-surge state (Robin and Weertman, 1973). This suggests that the ice sheet in the Mizuho Plateau may not be in a stable state.

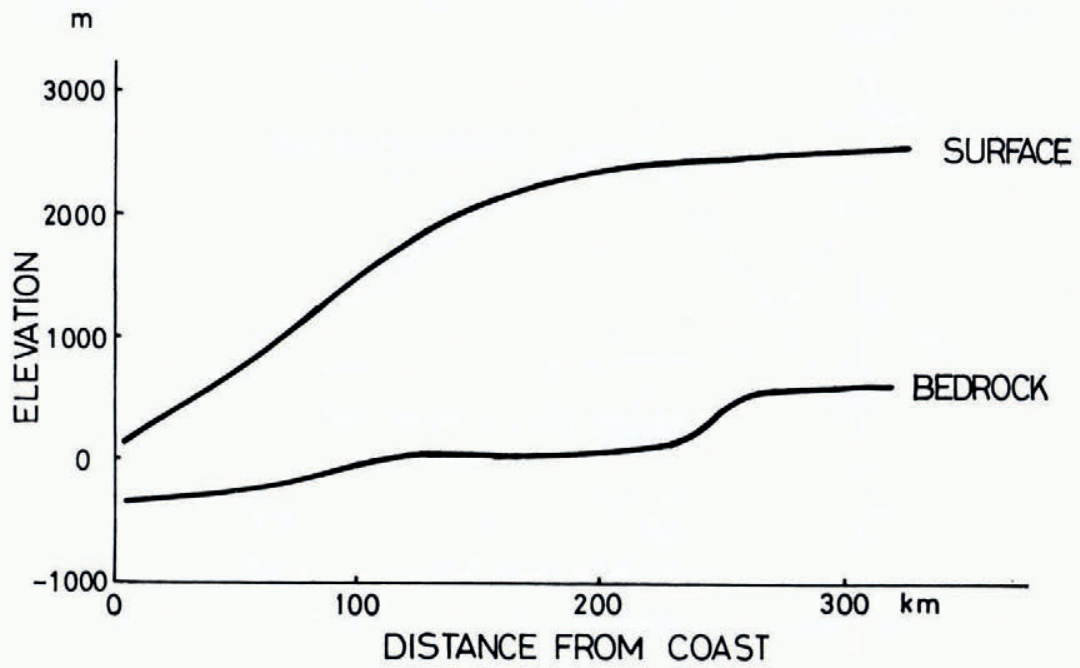

Fig. 6. The surface and vedrock topography along the central flow line.

\section{Discussion}

The estimation of the basal sliding velocity indicates that basal sliding is occurring over a main part of the traverse route; that is at least over that section of the route in the northern part of the Shirase Glacier drainage basin, basal sliding occurs and the base is wet. This may be a reason for the rapid motion of the Shirase Glacier, $u_{\mathrm{s}}=2.2 \mathrm{~km} /$ year (Fujiwara and Yoshida, 1972). From Figure $\mathrm{I}$ it is seen that the surface elevation is lower in the central area of the Shirase Glacier drainage basin than near the boundary of the basin. If the lowering of the surface is caused by thinning of the ice sheet due to basal sliding, the thinning commenced about $2 \times \mathrm{IO}^{2}$ years ago because the lowering is about $100 \mathrm{~m}$ at the traverse route. This result for the age of the thinning is supported by analysis of the temperatures of a core hole at Mizuho Station. Therefore, we can propose that the area of basal sliding and wet base has been expanding from the northern part of the basin and reached the traverse route about 200 years ago provided that the thinning-rate was constant.

If the basal sliding is caused by a rise of ice temperature at the base, the following two causes are conceivable:

(I) a decrease in the accumulation-rate,

(2) a rise of air temperature. 
Robin (1955) calculated the temperature profile of an ice sheet based on a simple steady-state model of heat conduction, and showed that the temperature difference between the surface and base increases as the accumulation decreases. A propagation time of temperature change from the surface to the base is $10^{4}$ to $10^{5}$ years. However, we have no information on accumulation-rate in the Mizuho Plateau since $10^{4}$ to $10^{5}$ years B.P., and it is impossible at present to determine which is the major cause of the rise of the base temperature.

It is conceivable that the Shirase Glacier should be classified as a fast-moving outlet glacier of the ice sheet and that the ice sheet of the Shirase Glacier drainage basin has the basal shear-stress curve shown in Figure 7 in a steady way. If this hypothesis were right, we could not explain the thinning of the ice sheet observed along the traverse route, nor our conclusion that the thinning commenced about $2 \times 10^{2}$ years ago and the wet-base area has been expanding from the down-glacier part of the basin.

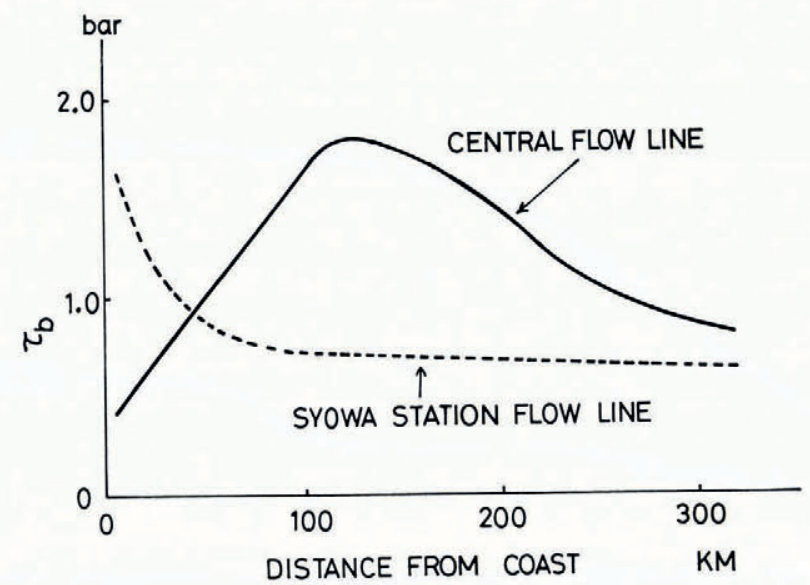

Fig. 7. The basal shear stress $\tau_{\mathrm{b}}$ along the central flow line and the Syowa Station flow line.

If a large amount of thinning occurs in West Antarctica; the mechanism of that thinning may be different from that in the Mizuho Plateau. The West Antarctic ice sheet forms one continuous body of ice with the Ross Ice Shelf. The base of the West Antarctic ice sheet over much of its area is at the startling depth of 0.5 to $\mathrm{I} \mathrm{km}$ below sea-level. Moreover, the bedrock would remain below the sea-level over a large area even if all the ice were removed and isostatic rebound occurred. Contrary to this, the base of the ice sheet in the Mizuho Plateau is above or at sea-level. For example, the base below the traverse route is about $500 \mathrm{~m}$ above sea-level and the base at the maximum $\tau_{\mathrm{b}}$ is at sea-level.

\section{REFERENCES}

Barnes, P., and others. 1971. Friction and creep of polycrystalline ice, by P. Barnes, D. Tabor, and J. C. F. Walker. Proceedings of the Royal Society of London, Ser. A, Vol. 324, No. 1557, p. 127-55.

Dansgaard, W., and Johnsen, S. J. 1969. A flow model and a time scale for the ice core from Camp Century, Greenland. Fournal of Glaciology, Vol. 8, No. 53, p. $215-23$.

Fujiwara, K., and Yoshida, Y. 1972. Ryutso-Horumu-wan tōgan no hyōga ryūdō sokutei [Ice flow measurements on the east coast of Lützow-Holm Bay [Antarctica]]. Nankyoku Shiryō: Antarctic Record, No. 44, p. 79-92.

Hughes, T. J. 1973. Is the West Antarctic ice sheet disintegrating? Journal of Geophysical Research, Vol. 78, No. 33,

p. 77884-910.
Mae, S. 1977. Hyōshō oyobi hyōga no hyōkōhenka no gen-in ni tsuite-nankyoku Mizuho-kōgen hyōshō to Nepäru Himaraya Kunbu hyōga no baai [The variation of the thickness of the Mizuho Plateau ice sheet, East Antarctica, and the Khumbu glacier, Nepal Himalaya]. Seppyō, Vol. 39, No. 3, p. i i 7-24. 
Mae, S. 1978. The bedrock topography deduced from multiple radar echoes observed in the Mizuho Plateau, East Antarctica. Nankyoku Shiryō: Antarctic Record, No. 61, p. 23-31.

Mae, S., and Naruse, R. 1978. Possible causes of ice sheet thinning in the Mizuho Plateau. Nature, Vol. 273 No. 5660 , p. $29 \mathrm{I}-92$.

Naruse, R. I978. Surface flow and strain of the ice sheet measured by a triangulation chain in Mizuho Plateau. (In Ishida, T., ed. Glaciological studies in Mizuho Plateau - west Enderby Land, East Antarctica, 1969-1975. Tokyo, National Institute of Polar Research, p. 198-226. (Memoirs of National Institute of Polar Research. Special
Issue No. 7.))

Naruse, R. 1979. Thinning of the ice sheet in Mizuho Plateau, East Antarctica. Fournal of Glaciology, Vol. 24, No. 9o, p. $45^{-52}$.

Naruse, R., and Yokoyama, K. 1975. Position, elevation, and ice thickness of stations. (In Naruse, R., ed. Glaciological research program in Mizuho Plateau-west Enderby Land, East Antarctica. Pt. 3, 1973-1974. Tokyo, National Institute of Polar Research, p. 7-47. (Japanese Antarctic Research Expedition. JARE Data Reports, No. 28 (Glaciology).))

Nishio, F., and Mae, S. In press. Temperature profile in the base ice area of the Yamato Mountains. [Memoirs of National Institute of Polar Research.]

Paterson, W. S. B. 1977. Secondary and tertiary creep of glacier ice as measured by borehole closure rates. Reviews of Geophysics and Space Physics, Vol. I5, No. I, p. 47-55.

Robin, G. de Q. 1955. Ice movement and temperature distribution in glaciers and ice sheets. Fournal of Glaciology, Vol. 2, No. 18, p. 523-32.

Robin, G. de Q., and Weertman, J. 1973. Cyclic surging of glaciers. Fournal of Glaciology, Vol. 12, No. 64, p. 3-18.

Shimizu, H. 1978. Outline of the studies of the glaciological research program in Mizuho Plateau, East Antarctica, 1969-1975. (In Ishida, T., ed. Glaciological studies in Mizuho Plateau-west Enderby Land, East Antarctica, 1969-1975. Tokyo, National Institute of Polar Research, p. I-13. (Memoirs of National Institute of Polar Research. Special Issue No. 7.))

Shimizu, H., and others. 1978. Morphological feature of the ice sheet in Mizuho Plateau, [by] H. Shimizu, A. Yoshimura, R. Naruse, and K. Yokoyama. (In Ishida, T., ed. Glaciological studies in Mizuho Plateau-west Enderby Land, East Antarctica, 1969-1975. Tokyo, National Institute of Polar Research, p. 14-25. (Memoirs of National Institute of Polar Research. Special Issue No. 7.))

Shōji, H., and Higashi, A. 1979. Mechanical properties of Antarctic deep-core ice. Journal of Glaciology, Vol. 24, No. 90 , p. $487-89$.

Shumskiy, P. A., and Bauer, A. 1965. Issledovaniye sovremennykh izmeneniy tsentral'noy chasti lednikovogo pokrova vostochnoy Antarktidy v $1964 \mathrm{~g}$. [Study of recent changes in the central part of the ice cap in East Antarctica in 1964]. Informatsionnyy Byulleten' Sovetskoy Antarkticheskoy Ekspeditsii, No. 51, p. $311-16$.

Yamada, T., and others. 1978. Distribution of accumulation measured by the snow stake method in Mizuho Plateau, [bX] T. Yamada, F. Okuhira, K. Yokoyama, and O. Watanabe. (In Ishida, T., ed. Glaciological studies in Mizuho Plateau - west Enderby Land, East Antarctica, I969-1975. Tokyo, National Institute of Polar Research, p. 125-39. (Memoirs of National Institute of Polar Research. Special Issue No. 7.))

Yokoyama, K. 1975. Net accumulation by stake measurements. (In Naruse, R., ed. Glaciological research program in Mizuho Plateau-west Enderby Land, East Antarctica. Pl. 3, 1973-1974. Tokyo, National Institute of Polar Research, p. 62-82. (Japanese Antarctic Research Expedition. JARE Data Reports, No. 28 (Glaciology).))

\section{DISGUSSION}

W. F. BudD: It is difficult to calculate the internal deformation because one needs to know the temperature distribution and the ice crystallography. What is the error on your estimate for internal deformation?

S. MAE: I think that the error of the calculated internal deformation is mainly caused by the calculation of the vertical temperature profile because I used a simple model. I believe that the stress-strain-rate relation obtained by Shöji and Higashi (1979) is more reliable than the temperature profile, and the ice crystallography causes a rather smaller error than the temperature profile.

R. H. Thомаs: Accumulation measurements in the catchment area of Shirase Glacier indicate that total accumulation is greater than outflow. How do you reconcile this with your estimates of thinning?

MAE : If the estimation of the total ice accumulation is correct, the positive mass balance in the Shirase Glacier drainage basin indicates that a thickening may take place down-glacier. We have not measured the thickness change in the other part and it is not clear whether thickening is taking place or not. 